\title{
Preventing Violent Extremism and Social Work: Recent US History and Prospects
}

\author{
Royce A. Hutson ${ }^{1}$ (D)
}

Accepted: 20 April 2021 / Published online: 1 July 2021

(c) The Author(s), under exclusive licence to Springer Nature Switzerland AG 2021

\begin{abstract}
Anti-immigrant, anti-Semitic, and anti-Muslim violent extremism is on the rise in Western nations while jihadist terrorism continues throughout the Middle East and Africa. Despite significant efforts by governmental, non-governmental, and civic society organizations to address violent extremism, little progress has been made to prevent it. White supremacist organizations are now organizing globally through a variety of next generation communication networks using techniques developed by ISIS and Al-Qaeda. Throughout, relatively few social work academics have engaged in preventing violent extremism (PVE) scholarship. Though the profession is referenced frequently in the PVE literature, it is dominated by those in psychology and political science. Few articles in major social work journals have discussed social work's role or advanced PVE research. What has been published has mainly been critical of social work in this arena for legitimate fears of securitization, lack of resources/training, and the potential to discriminate against particular groups. The profession has a long history of impactful work in violence prevention in a myriad of practice areas. Given this wealth of experience and focus on social justice, social work should be a leader in this field. Areas of potential engagement in practice and research are discussed.
\end{abstract}

Keywords Violent extremism $\cdot$ Hate crimes $\cdot$ Terrorism $\cdot$ Counterterrorism $\cdot$ White supremacy $\cdot$ Violence prevention

\section{Introduction}

The attacks on two mosques in Christchurch, NZ, that killed 51 in March, 2019, and the killing of 23 at an El Paso, TX, department store the following August, and most recently, the insurrection at the US Capital, illustrate the mounting rise of violent extremist ideology motivated by animus towards particular races, ethnicities, and nationalities, while radicalization of those inspired by ISIS and Al Qaeda (AQ) continues to inflict terror throughout the world. As the Easter bombings in Sri Lanka in April 2019 that killed 259 painfully demonstrated, the issue is not isolated to Western nations. Many of these groups continue their terrorism and recruitment in places throughout Africa and Southeast Asia despite efforts by governmental, non-governmental, and civil society organizations to combat violent extremism in their communities. The latest figures from 2017 estimated 10,900 terrorist attacks killed more than 26,400 people

Royce A. Hutson

roycehutson@boisestate.edu

1 School of Social Work, Boise State University, 1910 University Dr, Boise, ID 83703, USA
(Miller, 2018), and research suggests that there are over $2 \frac{1}{2}$ times more jihadist fighters than at $9 / 11$ (Jones et al., 2018). To compound these issues, with the fall of the so-called Islamic State (ISIS), countries that saw people recruited to ISIS ranks are now faced with not only repatriating the combatants but also the partners and children of these fighters.

To add to the danger, the recruitment and incitement to violence by extremist groups have morphed. White supremacist organizations from Europe, North America, Australia, and New Zealand are organizing with each other through a variety of next generation communication networks. In some cases, White supremacist groups and adherents are adopting the recruitment strategies of ISIS and Al Qaeda (DHS, 2019). An additional challenge posed is that Russia appears to be utilizing social media and other avenues to stoke racial/ethnic extremism in Ukraine, Europe, and the USA (Johnson, et al., 2019; Linvell \& Warren, 2018). In April, 2020, the White supremist group Russian Imperial Movement (RIM) was designated by the US Department of State (DoS) as a foreign terrorist organization, a first for a White nationalist organization.

The COVID-19 pandemic has augmented the threat. White supremacists, anti-government militias, and AQ/ISIS have 
used the emergency to accelerate their recruitment efforts further online through disinformation about the virus and its origins. "Acclerationists" in the White supremist and antigovernment movements have advocated for violent action to accelerate the overthrow of governments given the perceived decline in social order (Barak, 2020; ISD, 2020). The recent storming of the US Capital by right-wing extremists, antigovernment militias, and White supremacists, resulting in the deaths of five people, illustrates the US national security imperative of preventing violent extremism.

Though the social work profession is referenced frequently in the preventing violent extremism literature, relatively few social work academics have published in this arena. What has been published has primarily been critical of social work in PVE for legitimate fears of securitization of the profession, lack of resources/training, and the potential to stigmatize and discriminate against particular racial/ethnic and/or religious groups (e.g., Finch, 2019; McKendrick \& Finch, 2017; Stanley et al., 2018). This scholarship has emanated primarily from European social work scholars. The profession has a long history of impactful work in violence prevention in a myriad of practice areas: gang violence, school violence, dating violence, bullying, sexual assault, and child abuse to name a few. Given this wealth of experience, social work scholars should be a primary resource in this area. To understand the lack of social work scholarship in this arena, a history of this area of research should be given, and the role that social work scholarship has played to date.

\section{Brief History of Violent Extremism Prevention Approaches Since 9/11}

The full history of terrorism and preventing/countering violent extremism (P/CVE) studies is beyond the scope of this paper. However, it is important to note the sea change in research and intervention focus since 9/11. Starting from the 1960 s and prior to $9 / 11$, most discussions of terrorism revolved around organizations with clear nationalist objectives (e.g., IRA, PLO, ETA, Hizbollah, etc.), the sociology of these organizations (e.g., formation, trajectories, grievances, etc.) and the psychology around individuals who join these organizations (Nasser-Eddine et al., 2011). It was thought that social science could provide direction in preventing terrorist actions through prevention, often through identification of a terrorist "profile" and/or mental health diagnoses. Clear from this era of research, however, was that there was neither single psychological profile of a "terrorist" nor was there any unique mental health issues that predisposed a person to engage in terrorist activities (Horgan, 2014; Silke, 2006). Later research, however, demonstrated that "lone wolf" terrorists, those who act alone with little guidance or support, are 13.5 times more likely to be diagnosable for a mental illness than group-based terrorists (Corner \& Gill, 2015). Following the $9 / 11$ attacks, the USA significantly altered the framework in which terrorism and violent extremism would be addressed in practice and research.

Outside the immediate military and law enforcement responses, the questioning of motivators, the push, and pull factors began in earnest. The Bush administration initiated significant efforts in countering the recruitment anti-US "narrative" of Al-Qaeda through global public diplomacy, ultimately spearheaded by Karen Hughes in 2005 (Epstein, 2005). In that same year, the "Global War on Terror" was halted as the war in Iraq and Afghanistan raged on. In the aftermath, the US government announced a new initiative entitled, "the struggle against violent extremism" (NasserEddine et al., 2011). This was a significant reframing of the issue as "violent extremism," (i.e., ideology) as opposed to terrorism (an action). As reported at the time (Schmitt \& Shanker, 2005), Gen. Richard B. Myers, then chairman of the Joint Chiefs of Staff, stated that the US government "...objected to the use of the term 'war on terrorism' before, because if you call it a war, then you think of people in uniform as being the solution." He noted that, instead, AlQaeda and other Islamist terrorist organizations should be defined as violent extremists, and terrorism was the method that they employed. Steven J. Hadley, then National Security Advisor, stated that "It's [Global War on Terror] broader than that. It's a global struggle against extremism. We need to dispute both the gloomy vision and offer a positive alternative." Other Western countries would very soon begin to adopt the term "violent extremism" after the 7/7 bombing in London a month later (Nasser-Eddine et al., 2011; Schmid, 2013). Simultaneously, the term "counter-radicalization" was also employed, often synonymously with countering violent extremism. The term is still utilized and debate about the difference between radicalization, extremism, and violent extremism and the proper use of the terms remains a source of contention (UNODC, 2018).

In spite of the declining global opinion of the USA in the ensuing years, it was still believed that a robust public diplomacy campaign and countering the overall narratives of alQaeda (AQ) would substantially prevent violent extremism (VE) (Sageman, 2014). However, with the continued growth of AQ-affiliated groups and the rise of AQ-inspired lone wolf attacks, other prevention avenues were deemed necessary by academics and policy advocates. Despite increased research efforts, there remained an absence of identifiable characteristic traits for those at-risk to commit terrorist acts, outside notable demographic features common in criminology (e.g., young males, see Klausen et al., 2016). In the late 2000s, given the lack of advancement in PVE objectives using counter-narratives and public diplomacy, public health/social work practice models were then advocated as a primary avenue to 
meet PVE objectives (Hutson et al., 2009; Weine et al., 2009). The thinking rapidly caught on. In the past decade, multiple scholars, think tanks, and advocates have advocated for using public health and social work models for PVE (e.g., Bosley, 2019; Ellis \& Abdi, 2017; RAN, 2016). Notably absent from this recent scholarship on PVE are US social work academics, with a few exceptions (e.g., Hutson et al., 2009; Ellis \& Abdi, 2017). However, some sound critiques and discussions in the literature on social work in countering terrorism from European social work scholars (e.g., Finch et al., 2019; Haugstvedt, 2019; McKendrick \& Finch, 2017). This scholarship has often been critical of the underlying assumptions of the prevention models that target youth deemed at risk, for example, the PREVENT/Channel program in the United Kingdom (UK) (Awan \& Guru, 2017; Stanley et al., 2018; Stanley \& Guru, 2015; Guru, 2010).

\section{Current Global "Good Practice" in PVE: Social Work and Public Health}

With the end of the "war on terror" and movement towards reframing the problem as a public health issue, there was a global movement by individual governments, INGOs, and multilateral organizations to create "good practice" frameworks. The multiple frameworks proposed shared substantial similarities regarding the use of social work practice models. The Global Counterterrorism Forum (GCTF), the United States Institute of Peace (USIP), Hedayah, the Global Community Engagement and Resiliency Fund (GCERF), Radicalization Awareness Network (RAN), US Department of State (DoS), and the United Nations Office of Counterterrorism (UNOCT) among others identified social work methods as a major component in good practice models for PVE. The recommendations for social work engagement cut across the social ecology. The need for psychosocial support is frequently mentioned in rehabilitation models for former violent extremists (VE) and in working with family members of VEs. In PVE good practice discussions, the models employ community organization, logic modeling/theory-of-change, and evaluation planning methods common in macro-social work and public health prevention work. However, of particular note in this literature is the recommendations for community resilience building, a common community-level practice. Standard social work terminology and approaches, such as a strengths focus, empowerment, trauma-informed, and ecological models of prevention/intervention (aka "wholeof-society"), are ubiquitous in this literature. Further, with substantial increases in White supremacist organizational activity, these conversations on public health/social work approaches accelerated (Bosley, 2019; Rosand et al., 2018; NAS, 2017; RAN, 2016; GCTF, 2016a; GCTF, 2016b).
Surprisingly, these frameworks either do not acknowledge the input of social work professionals or do not include them at all while employing explicit "social work" language. Below is an example from the GCTF on good practices for children and families of foreign terrorist fighters (FTF) in Syria/Iraq (2018). With the fall of the so-called ISIS caliphate in Syria/Iraq, over 60,000 family members of ISIS fighters from other countries have been rounded up and placed in internally displaced camps in Northeast Syria. The repatriation, rehabilitation, and reintegration of these families are currently a top priority for the US government and numerous multilateral organizations to prevent a new generation of ISIS-inspired extremists:

It is essential for any response policy to be traumainformed and focus on the strengths of the returnee to encourage a sense of empowerment to combat the loss of control that is a primary aggravator of trauma and can be magnified by a reintegration process controlled by others. Traumatization is not a static event; it is a dynamic process that becomes more complex over time, and living with violent conflict in unstable political or social environments can compound trauma. Repeat victimization related to discrimination, stigmatization, unemployment, and the absence of peer networks or socialization is a serious concern. It demands trauma awareness training to recognize trauma signals for all individuals likely to be in contact with returning family members and a gradual, phased approach to addressing trauma that emphasizes safety, coping strategies, relationship-building, and stability before processing the trauma memories (p. 5).

In 2017, RAN published a 102-page piece entitled, "Responses to Returnees: Foreign Terrorist Fighters and their Families," regarding the psychosocial care of FTF returnees. All four authors were outside social work or psychology. This was followed up in 2020 by a piece regarding rehabilitation of terrorist offenders entitled, "Rehabilitation Manual - Rehabilitation of Radicalised and Terrorist Offenders for First Line Practitioners" with 168 mentions of the term "social work" in just over a hundred pages. None of the six identified authors was a social work academic, with all being in either law, sociology, or political science/ security studies.

\section{Preventing Violent Extremism in the US: The Current Movement Towards Prevention}

Law enforcement approaches were initially at the forefront of the US response to violent extremism. At the advent of the PVE discussions in the US, the potential for and actual examples of the targeting of groups and communities deemed potentially "radicalized" by law enforcement 
turned many in the helping professions off to engagement in the area. The US Department of Homeland Security (DHS) admitted in the most recent counterterrorism framework that counterterrorism efforts initially focused primarily on AlQaeda (AQ)-inspired domestic terrorism after 9/11 (DHS, 2019). Examples by state, local, and national law enforcement in the targeting of Muslim communities resulted in deserved public backlash. This discrimination was exacerbated considerably by anti-immigrant and anti-Muslim rhetoric in public discourse, and worsening divisions between law enforcement, community leaders, and civil society organizations. The stigmatization of Muslim-majority communities was further exacerbated when 22 young Somalis departed for Somalia to fight with the terrorist group AlShabab ("The Youth") in 2008 (see Ellis \& Abdi, 2017 for a review). A silver lining to this event, however, was a renewed focus on drivers of VE among Somali youth, and subsequently, other demographic groups (Ellis et al., 2016; US Senate Committee on Homeland Security and Government Affairs, 2009). This renewed focus would ultimately come to include extremists outside of Islamist-inspired violent extremism.

With the recent rise of White supremacist ideology over the past few years, the US government has now recognized "racially and ethnically motivated violent extremism" (REMVE) on par with AQ- and ISIS-inspired terrorism (DHS, 2019). The DHS's latest strategic framework described the threat this way,

White supremacist violent extremism, one type of racially- and ethnically-motivated violent extremism, is one of the most potent forces driving domestic terrorism. Lone attackers, as opposed to cells or organizations, generally perpetrate these kinds of attacks. But they are also part of a broader movement. White supremacist violent extremists' outlook can generally be characterized by hatred for immigrants and ethnic minorities, often combining these prejudices with virulent anti-Semitism or anti-Muslim views (p. 10).

Further, DHS (2019) noted that White supremacist ideologues have adopted a "transnational outlook" in the past few years. This has been facilitated by the use of encrypted communication apps, chan boards (e.g., 8chan, EndChan), and applications like Gab, with communication between White supremacists of Western countries common. The phenomenon is exacerbated considerably by the Russian Federation stoking racial/ethnic animosity online in the US to meet their foreign policy objectives of delegitimizing Western democracies (Johnson et al., 2019; Linvell \& Warren, 2018).

Following the lead from initiatives to counter violent extremism abroad, in 2011, the US government released empowering local partners to prevent violent extremism in the USA with examples given of successful youth violence prevention programs that could be adapted to the PVE context (White House, 2011). The current US Government's stated role for the social work profession in addressing VE is a mirror of US foreign policy for social work interventions in P/CVE. Again, social work is seen as a major actor throughout the social ecology. However, there is little note of social work's role in policy advocacy on broader social justice issues that address the push factors of VE, that is, addressing the underlying "grievances" driving radicalization. In the mind of many policy experts that this author has spoken to in his role as National Academies of Sciences, Engineering, and Medicine (NAS) Jefferson Science Fellow (JSF) at the US Department of State, Bureau of Counterterrorism, Office of Countering Violent Extremism (CT/ CVE), there is considerable debate about where PVE ends and social development and human rights advocacy begins. With that, there is an understanding that development and governance matter immensely to the overall sustainability of PVE gains (US Department of State \& Agency for International Development, 2016). This attempt at disentanglement between social development, social exclusion, and PVE is extremely troubling and may reflect the lack of social work professional engagement. Further, the employment of euphemisms for human rights abuses, state-sponsored violence, corrupt/non-responsive governance, etc. (i.e., "grievances") diminishes greatly the role these social injustices have in driving people to extremism.

More recently, several US academics have proffered models for PVE that generally seek to improve social cohesion between community sectors and within families. Unfortunately, empirical evidence on primary prevention strategy efficacy is scant, and recent models put forth missing primary adolescent prevention programs from their discussion, with some exceptions (e.g., Ellis \& Abdi, 2017). More typically advocated are secondary prevention models that utilize risk assessment (e.g., Wiene et al., 2017) and subsequent interventions with identified at-risk youth. Given the lessons from the UK's PREVENT/CHANNEL program and the targeting of Muslim communities in the US, this direction could be troubling, and why a social justice-oriented social work lens is vital to this work. The most recent examples of these views on social work's role in PVE within the US can be seen in the FEMA-sponsored trainings offered through the University of Maryland's START consortium (START, 2019) and the DHS's counterterrorism framework (2019).

\section{Lessons from the UK: The Need for a Critical Social Work Lens}

The insightful work of Tony Stanley and Surinder Guru stands as timely reminders of the ethical and social justice pitfalls work in this field presents. But as importantly, it illustrates the necessity of a critical social work lens to 
understanding the social justice imperative in PVE. Critical of Britain's PREVENT and CHANNEL programs and policies, they have added rich discussion on the role of social work direct practice in the PVE context. In brief, these policies encompass local and national multisector planning and coordination to address radicalization of children. The rational is through a doctrine of "safeguarding and promoting the welfare of children," a child protection paradigm. This view is considered a contentious lens by Guru and others for understanding and addressing violent extremism prevention as it diminishes primary social justice factors related to VE and places blame on parents. The PREVENT DUTY component is also quite controversial as it encompasses the reporting individuals exhibiting early features of radicalization to violence to the CHANNEL program. The CHANNEL program is voluntary and incorporates an assessment by a panel of local child welfare stakeholders and professionals. If the referral is deemed sufficient for further intervention, the person is referred to individualized services that meet the potential drivers of radicalization. The identification of these at-risk children is wrought with social justice issues along with the programming itself. It has been roundly criticized for reasons such as targeting muslim-majority communities and children, stigmatizing children referred to CHANNEL, lack of empirically validated "symptoms" of radicalization, paucity of training/resources, and the securitization of the profession. Uproar over the program resulted in the UK Home Office commissioning a review of the program in 2019. In the prior year, of the 7318 referrals, only 5\% (394) were sent on for CHANNEL support (Warrell, 2019; Stanley et al., 2018; Awan \& Guru, 2017; Stanley et al., 2017; Stanley \& Guru, 2015; UK Department of Education, 2015).

\section{Social Work Engagement in PVE: a Call to Action}

While European social work academics are slowly building a body of literature on PVE, throughout the author's experience as a Jefferson Science Fellow at the US Department of State's Bureau of Counterterrorism (2019-2020) and now Senior Advisor, few US social work academics were publishing on the implementation of PVE programs explicitly. There is one notable exception, Dr. Saida Abdi's excellent work with Harvard Psychology Professor Dr. Heidi Ellis on Somali-American communities (e.g., Ellis \& Abdi, 2017; Ellis et al., 2016, 2019). Also, conspicuously absent from these conversations were international social work organizations. This is not to disparage groups such as the International Federation of Social Workers (IFSW), the International Association of Schools of Social Work (IASSW), and the International Consortium for Social Development who have done great work in conflict-affected areas. However, a recent press release by the IFSW is illustrative of the level of engagement in PVE. In large part addressing the rise of populism and anti-immigrant sentiment in Europe, the IFSW outlined 10 resolutions based primarily on social justice objectives, clearly a primary paradigm in the profession. However, only one of the 10 resolutions presented discussed improving the delivery of social work in this area of "social crisis" that included racism and xenophobia. Though laudable, the resolution does not prominently address the need for engagement in promoting evidence-based practices in individual or community intervention/prevention. Advocating for social justice objectives and improving practice in this arena can and should be conducted simultaneously (IFSW, 2019).

\section{Ways Forward}

Rejection or ambivalent engagement in PVE by social work practitioners and academics, though understandable, is a mistake. This work will continue with or without social workers at the table. While the targeting of minority communities and individuals through a variety of law enforcement and community programs continues in the name of global/ national security, advocating for a socially just approach to PVE using empirically and theoretically supported prevention models should be advocated. Social workers have rightly criticized these initiatives through advocacy and consciousness-raising. However, excluding the few exceptions acknowledged, social work on whole has not provided an alternative to addressing this new generation of violent extremism. The fields of psychology/psychiatry and political science dominate PVE and borrow liberally from the social work and public health canons in both prevention and adolescent/young adult mental health. While improved mental health care, access to care, and early intervention for mental health crises is laudable, the primary gap in social work academic involvement is in prevention. The mental health care of young people traumatized, suffering mental health or developmental crises, and those disaffected is studied intensely in a variety of settings. Further, while associated with right-wing lone wolf attacks, mental health is not a primary driver of most forms of radicalization. Social workers in Norway, for example, were found to treat potentially radicalized youth as they would any social problem (Haugstvedt, 2019). Unfortunately, what is ignored in this scholarship is reference to specific, empirically validated social work prevention models that appear to have direct applicability to PVE. Further, references to social justice issues related to PVE, often termed "grievances," are discussed cursorily among PVE practitioners.

As with traditional violence prevention initiatives, social work engagement can result in effective and humane 
approaches with social justice and human rights at the forefront. There are three prominent avenues in which social work can inform best practices in PVE; research and scholarship, social work education, and policy advocacy.

\section{Research to Practice}

Well-regarded terrorism scholar Marc Sageman has been notably critical of terrorism research, suggesting that basic research in terrorism is missing serious scientific rigor (Sageman, 2014). He is not alone (see Silke, 2019 for a review). In 2009, only 35\% of scholarship was primary data collection (Silke, 2009). In Schuurman's (2020) review of 2552 research papers on terrorism conducted between 2007 and 2016 in 9 leading terrorism journals, $78.1 \%$ did not use any statistical analysis; less than $1 \%$ used an experimental design. Unfortunately, the term "evidence-based" has become the term of the day in PVE and is grossly misused. Numerous private development companies/consultancies note that their PVE programs are "evidence-based" yet provide little if any documentation to substantiate these claims. Though this may be partly as a result of confidentiality/ clearance issues (Sageman, 2014) or be buried in governmental reports (Hutson et al., 2010). With that, evidence cited is often anecdotal, pilot/pre-experimental, low N, and/ or tangentially related to PVE objectives. In this author's role in identifying and vetting potential PVE implementers, I encountered a paucity of truly evidence-based programs in CVE. If empirical evidence is presented by firms, they are typically around efficacy in addressing mental health, not VE ideology (or deradicalization), reintegration, or violence prevention outcomes. In the PVE academic literature, a substantial proportion is around model proposals (e.g., War Child, 2019; Ellis \& Abdi, 2017; Wiene, et al., 2017), not experimental or even pre-experimental research. In Ellis and her colleagues' defense, they have conducted sound primary research on the psychosocial drivers of VE among SomaliAmerican refugee youth (Ellis et al., 2016). Their partnership is an excellent example of interdisciplinary work in which a social work lens in prominent in the scholarship.

The stakes in the absence of social work academics in this arena are high. Some recent models proposed by prominent scholars in psychology/psychiatry for PVE are looking at this through a mental health lens that seeks to identify atrisk youth/young adults for intervention (Weine \& Kansal, 2019; Wiene, et al., 2017). Though well-intentioned, this approach is misguided. Prioritizing preventing VE ideology in the first place over identifying young people "at-risk" for espousing VE is the way forward. Past experience demonstrates that "at-risk" youth has often been a dog whistle for minority and/or disempowered youth. That path has met with justifiably serious social justice critiques, especially in this context, and at its core a psychologizing deficits-based approach. Further, efforts at assessing for radicalization have met with a host of serious impediments. Currently, radicalization risk assessment instruments with excellent reliability and validity simply do not exist. Though some broad drivers of VE have been identified, it is not currently possible to predict who eventually will espouse VE ideology, let alone engage in violence as the base rate of terrorist action is low even among those espousing violent extremist ideologies. Given the extraordinarily low base rate and the real threat of a false positive paradox, any public mental health initiative should be approached as furthering overall community well-being and disentangled from PVE. Social workers who have worked in this field suggest that youth identified as atrisk for VE may be at-risk for a host of other poor outcomes (Haugstvedt, 2019).

Social work scholarship has led the way in strengthfocused, empowerment-oriented prevention research for decades, especially violence prevention research. Violence prevention is an often-cited analogue for PVE logic modeling (Selim, 2016). However, translation of any of these approaches, school- and/or community-based, have yet to be studied at length. With numerous prominent prevention research centers located throughout schools of social work along with a host of social work academics/practitioners in this space, the infrastructure is available to pivot into this field of research and evaluation. The prevention frameworks employ techniques that may have PVE impacts vis-a-vis human rights education, tolerance/acceptance programming, and critical thinking. Funding for program delivery and evaluation is available through a variety of governmental departments: Department of Defense, Department of Justice, Department of State, and USAID have all funded PVE programming in the recent past domestically and abroad. PVE research funding in the EU is also available through home governments and the EU.

\section{Social Work Education}

Though numerous schools of social work have explicit prevention curricula, prevention practice broadly should be explicitly required curriculum content. Currently, the term "prevention" is used twice in the 2015 CSWE Educational Policy and Accreditation Standards (CSWE, 2015). Requiring prevention studies would not just be a theoretical exercise as empirically validated social work violence prevention activities are ubiquitous across the USA: bullying, domestic violence, child abuse, sexual assault, and gang prevention being notable areas. These programs are the basis for current program modeling in PVE. Education on violence prevention programing alongside macro-social work education on community-level social cohesion building across and within identity groups should be standard curriculum. Introductory macro-social work courses should also be required 
to address community resiliency-building as a core skill set. Ellis and Abdis' (2017) work with Somali-American youth and the communities they live in suggest that this approach may have merit. Social cohesion, an integral part of resiliency-building, is already covered in macro-social work texts. Drawing a line from fostering social cohesion, to resiliency building in the event of disasters, or to prevent bigoted violence is fairly direct.

\section{Policy Advocacy}

Any hope for long-term sustainability in PVE must address social justice issues. Grievances have been demonstrated to be a substantial push factor to VE. The grievances often center on exclusion: social, political, economic, and cultural. Additionally, searching for a meaningful identity resulting from disempowerment appears to be a pull factor to VE. Interviews with captured and former terrorists suggest that many saw their activities as a higher calling. Given the perceived injustices against their fellow compatriots, it was their duty to engage in violence to ameliorate the injustice, seek a sense of purpose, and achieve social status (see Khalil et al., 2019 for a review). State-sponsored human rights abuses and violence, extreme economic dislocation, and other social injustices have been recognized as primary drivers of extremism. Continued social justice advocacy has significant security implications, and depending on circumstances, may need to be couched as such. A more just society outcome is one in which grievances, and therefore push factors, are diminished. Providing for opportunity and social inclusion will also moderate the pull factors.

Augmenting abuse prevention activities could also have significant PVE impacts. Traumatic experiences have also been shown to be associated with VE, with a large proportion of "lone wolf" actors having been victims of some form of abuse (Corner \& Gill, 2015). Improving access to quality mental health care for those with trauma histories should also have substantial PVE impacts. Aligning somewhat with those who propose secondary prevention efforts that center on mental health, advocating for increased screening and access to care for trauma-related mental health problems for children and young adults is also a PVE policy issue. Like with social justice advocacy, framing an increase in mental health screening/access as a security issue may open avenues for support that may not be available through more traditional funding mechanisms.

At the global level, international social work organizations such IFSW and IASSW can play integral roles in working with and advocating to the UN and other multilateral organizations in the adaptation of social work approaches to the PVE context. Further, they can provide much needed guidance on the rehabilitation and reintegration of former fighters and their families to these organizations. Social work scholarship with child soldiers, and to a lesser extent, DDR (demobilization, disarmament, and reintegration), can provide much needed direction in this area of work.

\section{Conclusion}

Globally and domestically, social work has been called upon to address the rise of VE at all levels of intervention by counterterrorism experts. The reasons for trepidation by the profession are understandable and justifiable. However, without substantial input by social justice and strength-focused social work professionals at the table, there is substantial risk that PVE programs will make the mistakes of the past. Recent lessons from UK PREVENT demonstrate this to be the case. From this author's experience in this field, there is little doubt that current programs are well-intentioned. Justifiably, many programs borrow liberally from social work theories. The concern is that the underlying meaning and intention of social work activities as social justice endeavors may be somewhat lost on practitioners outside the profession. It is through active engagement with our like-minded helping professional colleagues in other disciplines in PVE that we can advance a social justice-oriented vision of violent extremism prevention.

\section{References}

Awan, I., \& Guru, S. (2017). Parents of foreign "terrorist" fighters in Syria - Will they report their young? Ethnic and Racial Studies, 40(1), 24-42. https://doi.org/10.1080/01419870.2016.1206588

Barak, M. (2020) The corona pandemic: An opportunity of ISIS, International Institute for Counter-Terrorism. https://www.ict.org. il/images/Corona\%20and\%20ISIS\%20-\%20Eng.pdf

Bosley, C. (2019). Injecting humanity: Community-focused responses for people exiting violent extremist conflict. United States Institute of Peace. https://www.usip.org/publications/2019/08/injectinghumanity-community-focused-responses-people-exiting-violent

Corner, E., \& Gill, P. (2015). A false dichotomy? Mental illness and lone-actor terrorism. Law and Human Behavior, 39(1), 23-34. https://doi.org/10.1037/lhb0000102

Council on Social Work Education (CSWE). (2015). Education Policy and Accreditation Standards. Retrieved from https://www.cswe. org/getattachment/Accreditation/Standards-and-Policies/2015EPAS/2015EPASandGlossary.pdf.aspx

Department of Homeland Security (DHS). (2019). Strategic framework for countering terrorism and targeted violence. https://www. dhs.gov/sites/default/files/publications/19_0920_plcy_strategicframework-countering-terrorism-targeted-violence.pdf

Ellis, B. H., \& Abdi, S. (2017). Building community resilience to violent extremism through genuine partnerships. American Psychologist, 72(3), 289-300. https://doi.org/10.1037/amp0000065

Ellis, B. H., Abdi, S. M., Lazarevic, V., White, M. T., Lincoln, A. K., Stern, J. E., \& Horgan, J. G. (2016). Relation of psychosocial factors to diverse behaviors and attitudes among Somali refugees. American Journal of Orthopsychiatry, 86(4), 393-408. https:// doi.org/10.1037/ort0000121 
Ellis, B. H., Sideridis, G., Miller, A. B., Abdi, S. M., \& Winer, J. P. (2019). Trauma, trust in government, and social connection: How social context shapes attitudes related to the use of ideologically or politically motivated violence. Studies in Conflict and Terrorism. Advance online publication. https://doi.org/10.1080/10576 10X.2019.1616929

Epstein, S. (2005). US public diplomacy: Background and the 9/11 commission recommendations. Congressional Research Service. https://fas.org/sgp/crs/misc/RL32607.pdf

Finch, J., \& Jönsson, J. H., Kamali, M. \& McKendrick, D. (2019). Social work and countering violent extremism in Sweden and the UK. European Journal of Social Work. Advance online publication. https://doi.org/10.1080/13691457.2019.1657803

Global Counterterrorism Forum (GCTF). (2016a) The role of families in preventing and countering violent extremism: Strategic recommendations and programming options. https://www.thegctf.org/ Tools/Overview

Global Counterterrorism Forum (GCTF). (2016b). Good practices on addressing the challenge of returning Families of Foreign Terrorist Fighters (FTFs). https://www.thegctf.org/Portals/1/ Documents/Framework\%20Documents/C/GCTF-Good-Practices-onReturning-Families-of-FTFs_ENG.pdf?ver=2018-09-25-101427-323

Global Counterterrorism Forum (GCTF). (2018). Addendum to the GCTF good practices on women and countering violent extremism, with a focus on mainstreaming gender. https://www. thegctf.org/LinkClick.aspx?fileticket $=\mathrm{jA} 1 \mathrm{tbXKhobE \% 3d \&}$ portalid $=1$

Guru, S. (2010). Social work and the 'war on terror.' British Journal of Social Work, 40, 272-289. https://doi.org/10.1093/bjsw/bcn129

Haugstvedt, H. (2019). Trusting the mistrusted: Norwegian social workers' strategies in preventing radicalization and violent extremism. Journal for Deradicalization, 19, 149-183.

Horgan, J. (2014). The psychology of terrorism (2nd Ed.). Routledge.

Hutson, R. A., Long, T., \& Page, M. (2009). Pathways to violent radicalization in the Middle East: A model for future studies of transnational Jihad. RUSI Journal, 154(2), 18-26. https://doi.org/10. 1080/03071840902965570

Hutson, R. A. Harris, A., Long, T., Page, M., Challita, L., Hanafi, S., Shannon, H., \& Salamey, I. (2010). The Palestinian camps in Lebanon: An evidence-based approach to identifying and countering causes and processes of radicalization. Beirut, Lebanon: Pursue, Ltd. (Report to the Foreign \& Commonwealth Office United Kingdom).

Institute for Strategic Dialogue (ISD). (2020). Covid-19 disinformation briefing No.1. https://g8fip1kplyr33r3krz5b97d1-wpengine.netdna-ssl.com/ wp-content/uploads/2020/03/Briefing-Covid-19.pdf

International Federation of Social Workers. (2019). Social workers respond to the growing social crisis in Europe. https:// www.ifsw.org/social-workers-respond-to-the-growingsocial-crisis-in-europe/

Johnson, N. F., Leahy, R., Restrepo, N. J., Valasquez, N., Zheng, M., Manrique, P., Devkota, P., \& Wuchty, S. (2019). Hidden resilience and adaptive dynamics of the global online hate ecology. Nature, 573, 261-265. https://doi.org/10.1038/s41586-019-1494-7

Jones, S. G., Vallee, C., Newlee, D., Harrington, N., Sharb, C., \& Byrne, H. (2018). The evolution of the Salafi-Jihadist threat: Current and future challenges from the Islamic State, Al-Qaeda, and other groups. Center for Strategic and International Studies. https://www.csis.org/analysis/evolution-salafi-jihadist-threat

Khalil, J., Horgan, J. \& Zeuthen, M. (2019). The Attitudes-Behaviors Corrective $(\mathrm{ABC})$ model of violent extremism, terrorism and political violence. Terrorism and Political Violence. Advance online publication. https://doi.org/10.1080/09546553.2019.1699793

Klausen, J., Morrill, T., \& Libretti, R. (2016). The terrorist age-crime curve: An analysis of American Islamist terrorist offenders and age-specific propensity for participation in violent and nonviolent incidents. Social Science Quarterly, 97(1), 19-32. https://doi.org/ 10.1111/ssqu.12249

Linvell, D. L., \& Warren, P. L. (2018). Troll factories: The internet research agency and state-sponsored agenda building. https://www. rcmediafreedom.eu/Publications/Academic-sources/Troll-FactoriesThe-Internet-Research-Agency-and-State-Sponsored-AgendaBuilding

McKendrick, D., \& Finch, J. (2017). 'Under heavy manners?' Social work, radiscalisation, troubled families and non-linear war. British Journal of Social Work, 47, 308-324. https://doi.org/10. 1093/bjsw/bcv141

Miller, E. (2018). Global terrorism in 2017. National Consortium for the Study of Terrorism and Responses to Terrorism. https://www.start. umd.edu/pubs/START_GTD_Overview2017_July2018.pdf

Nasser-Eddine, M., Garnham, B., Agostino, K. \& Caluya, G. (2011). Countering violent extremism (CVE) literature review. Australian Government, Department of Defense. https://apps.dtic.mil/ docs/citations/ADA543686

National Academies of Sciences (NAS), Engineering, and Medicine. (2017). Countering violent extremism through public health practice: Proceedings of a workshop. National Academies Press.

Radicalization Awareness Network (RAN). (2016). Ex post paper Handbook on How to set up a multi-agency structure that includes the health and social care sectors? Retrieved from https://ec.europa.eu/home-affairs/sites/default/files/whatwe-do/networks/radicalisation_awareness_network/ranpapers/ docs/ex-post-paper-handbook-ran-hsc-18-19-may-2016copenhagen-dk_en.pdf

Rosand, E., Winterbotham, E., Jones, M., \& Praxi-Tabuchi, F. (2018). A roadmap to progress: The state of the global P/CVE agenda. The Prevention Project and Royal United Services Institute.

Sageman, M. (2014). The stagnation in terrorism research. Terrorism and Political Violence, 26(4), 565-580. https://doi.org/10.1080/ 09546553.2014.895649

Schmid, A. P. (2013). Radicalisation, de-radicalisation, counterradicalisation: A conceptual discussion and literature review. International Centre for Counter-Terrorism. https://icct.nl/ publication/radicalisation-de-radicalisation-counter-radicalisationa-conceptual-discussion-and-literature-review/

Schmitt, E. \& Shanker, T. (2005, July 26) U.S. officials retool slogan for terror war. New York Times.

Schuurman, B. (2020). Research on terrorism, 2007-2016: A review of data, methods, and authorship. Terrorism and Political Violence, (5), 1011-1026. https://doi.org/10.1080/09546553.2018. 1439023

Selim G. (2016). Approaches for Countering Violent Extremism at Home and Abroad, 668(1). https://doi.org/10.1177/0002716216 672866

Silke, A. (2019). The study of terrorism and counterterrorism. In A. Silke (Ed.), Routledge handbook of terrorism and counterterrorism. Routledge.

Silke, A. (2009). Contemporary terrorism studies: Issues in research. In R. Jackson, M. B. Smyth, \& J. Gunning (Eds.), Critical terrorism studies: A new research agenda. Routledge.

Silke, A. (2006). The role of suicide in politics, conflict, and terrorism. Terrorism and Political Violence, 18(1), 35-46. https://doi.org/10. 1080/09546550500383241

Stanley, T., Guru, S., \& Gupta, A. (2018). Working with PREVENT: Social work options for cases of 'radicalisation of risk.' Practice, 30(2), 131-146. https://doi.org/10.1080/09503153.2017.1414176

Stanley, T., \& Guru, S. (2015). Childhood radicalization risk: An emerging practice issue. Practice, 27(5), 353-366. https://doi. org/10.1080/09503153.2015.1053858 
Stanley, T. \& Guru, S., \& Coppock, V. (2017). A risky time for Muslim families: Professionalised counter-radicalisation networks. Journal of Social Work Practice, 31, 477-490. https://doi.org/10.1080/ 02650533.2017.1394829

START. (2019). FEMA countering violent extremism training courses. https://www.start.umd.edu/FEMACVEtraining

UK Department of Education. (2015). The prevent duty: Departmental advice for schools and childcare providers. UK Department of Education.

UNODC. (2018). "Radicalization" and "violent extremism." https://www. unodc.org/e4j/en/terrorism/module-2/key-issues/radicalizationviolent-extremism.html

US Department of State and Agency for International Development. (2016). Department of State \& USAID Joint Strategy on Countering Violent Extremism. https://www.usaid.gov/sites/default/files/ documents/1866/FINAL\%20--\%20State\%20and\%20USAID\% 20Joint $\%$ 20Strategy $\%$ 20on\% 20Countering \% 20Violent\% 20Extremism\%20(May\%202016).pdf

US Senate Committee on Homeland Security and Government Affairs. (2009). Violent Islamist Extremism: al-Shabaab Recruitment in America. Retrieved from https://www.hsgac.senate.gov/hearings/ violent-islamist-extremism-al-shabaab-recruitment-in-america

War Child. (2019). Rethink child soldiers: A new approach to the reintegration of all children associated with armed forces and groups. https://www.warchild.org.uk/whats-happening/news/itstime-rethink-child-soldiers
Warrell, H. (2019, January 24). Inside prevent, the UK's controversial anti-terrorism programme. Financial Times.

Weine, S., Horgan, J., Robertson, C., Loue, S., Mohamed, A, \& Noor, S. (2009). Community and family approaches to combating the radicalization and recruitment of Somali American youth and young adults: A psychosocial perspective. Dynamics of Asymmetric Conflict, 2(3), 181-200.

Weine, S., \& Kansal, S. (2019). What should global mental health do about violent extremism? Global Mental Health, 6, e14. https:// doi.org/10.1017/gmh.2019.12

White House. (2011). Empowering Local Partners to Prevent Violent Extremism in the United States. Retrieved from https://www.dhs. gov/sites/default/files/publications/empowering_local_partners. pdf

Wiene, S. M., Stone, A., Saeed, A., Shanfield, S., Beahrs, J., Gutman, A., \& Mihajlovic, A. (2017). Violent extremism. communitybased violence prevention, and mental health professionals. Journal of Nervous and Mental Disorders, 25(1), 54-57. https://doi. org/10.1097/NMD.0000000000000634

Publisher's Note Springer Nature remains neutral with regard to jurisdictional claims in published maps and institutional affiliations. 